\title{
Strategi SMP Terbuka Dalam Meningkatkan Mutu
}

\author{
Abai Manupak Tambunan \\ Institut Agama Kristen Negeri Tarutung \\ abai.tambunan@yahoo.com
}

\begin{abstract}
This study tries to describe the Open Junior High School in performance and service to improve quality with different strengths compared to other schools. This research was conducted using qualitative methods by using approach phenomenology. This study used a combination of method triangulation needed because each data collection method has its own weaknesses and strengths. By combining at least three methods, for example participatory observation, in-depth interviews, and document searches, then one method will cover each other's weaknesses so that the catch on social reality becomes more reliable. The results of this study indicate that Open Junior High School can use various strategies in teaching and learning activities thus making the characteristics of Open Junior High School.
\end{abstract}

Keywords: Strategy, Quality and Difference

\section{Article Info}

\section{PENDAHULUAN}

Salah satu ciri sekolah yang bermutu adalah dapat merespon kepercayaan masyarakat artinya, bagaimana pihak sekolah mampu memberikan pelayanan yang terbaik bagi anak bangsa sehingga menciptakan generasi yang bermutu dalam segala hal. Karena pada dasarnya setiap anak-anak (siswa) memiliki potensi untuk berkembang optimal sesuai potensi yang dimiliki dan pendidikan yang diperoleh (Farozin, 2012). berjalannya suatu proses pendidikan yang diharapkan kiranya mampu meningkatkan mutu pendidikan tersebut dengan cara langsung maupun tidak langsung berimplikasi pada peningkatan peradaban suatu generasi.

Mengingat perkembangan dunia IPTEK serta era globalisasi yang berkembang pesat maka semangat untuk mengkaderkan lulusan yang sesuai dengan tuntutan masyarakat maka pihak sekolah perlu melakukan pembenahan-pembenahan dalam hal sumber daya manusia yang profesional, manajemen yang handal, kegiatan belajar-mengajar yang berkualitas sebagai penunjang Generasi masa depan yang berkualitas dan berkarakter agar eksistensi bangsa dan negara serta agama dapat dipertahankan (Suriansyah\&,.2015), pernyataan tersebut sejalan dengan pemikiran Kastawi\&,.(2019) yang berkata bahwa keberhasilan pendidikan didukung dari berbagai faktor seperti keprofesionalan guru, sarana prasarana dan banyak penunjang lainnya.

Harapan terpenuhnya akses terhadap lembaga pendidikan baik agar mencapai suatu kualitas memang tidak lepas dari kendali ketersediaan sarana-prasana yang terstandar. hal tersebut merupakan tantangan dalam dunia pendidikan khususnya bagi para pelaksana perencanaan dan ahli-ahli manajemen, pengambil kebijakan urusan pendidikan yang notabene 
banyak menjadi bagian dari pemerintah sangat diprioritaskan sehingga kedepannya dibutuhkan ekstra kinerja untuk mengevaluasi sampai sejauh mana pembangunan pendidikan yang berorientasi kepada layanan pendidikan berkualitas pada masyarakat. Upaya strategi manajerial yang dikembangkan untuk menjamin sebuah organisasi (sekolah) seharusnya memiliki daya tahan dan daya kendali dari masa sekarang dan berkelajutan sampai masa yang akan datang yang seirama dengan tujuan pendidikan karakter yang selama ini terus digaunggaungkan, harapannya agar diusahakan dan dilanjutkan dengan mengacu pada grand design visi dan misi pemerintah dengan melibatkan seluruh komponen sekolah (Barus, 2015). darisemua pemahaman itu penulis mulai paham akan eksistensi suatu kerja sama dan keberlanjutan suatu program yang perlu di akomodir demi tercapainya tujuan bersama yaitu mutu pendidikan.

Pendidikan merupakan kebutuhan primer sehingga memiliki peranan yang sangat penting, pemahaman ini perlu ditekankan pada setiap lapisan masyarakat sehingga setiap anak bangsa berlomba untuk memperoleh pendidikan yang berkualitas meskipun fakta kehidupan masih ada juga ditemukan sebagian masyarakat dalam kategori tidak beruntung sehingga tidak dapat melanjutkan pendidikannya.

Pendidikan bisa diartikan sebagai mesin pencetak generasi, mutu adalah tujuan dan untuk mengarah kepada tujuan tersebut khususnya bagi komunitas tertentu sebagai penguna pendidikan umumnya mengalami hambatan dikarenakan hal yang sangat mendasar serperti ekonomi keluarga yang sangat minim serta faktor lingkungan yang tidak kondusif. Seperti diketahui pendidikan selama ini dapat ditempu secara formal disekolah dan informal di keluarga namun pada pendidikan formal faktanya tidak semua anak dapat merasakan duduk di bangku sekolahan disebabkan keadaan yang menghambat pemenuhannya dikarenakan faktor yang sudah disebutkan diatas. Keadaan 66 tersebut dengan tidak langsung mentuntut masyarakat untuk mencari jalan lain menuju kesuksesan sehingga terlihat lebih ekstra dan lebih giat lagi berupaya. untuk itu sewajarnya diadakan tindakan bahu membahu saling menolong antar sesama serta menuntut pemerintah melindungi serta membiayai anak-anak Indonesia yang terhalang dalam proses memperoleh pendidikan sesuai amanat UUD 1945 Republik Indonesia. Dalam pemenuhan nantinya harapannya semua masyarakat mudah mendapat fasilitas dan akses menempuh pendidikan, maka esensi pendidikan berupa kumpulan ilmu yang dapat dirasakan dan dinikmati sebagai suatu layanan yang cuma cuma. Hakikat serta keseluruhan upaya pendidikan juga dianggap suatu layanan berupa upaya bagi peserta didik ke arah tujuan tertentu, yaitu dalam rangka mengarahkan perkembangan peserta didik seoptimal mungkin (Hendrowobowo, 1994) serta didukung organisasi sehat dan tempat belajar yang nyaman sesuai fungsinya masing-masing dengan tujuan agar siswa belajar dan mencapai hasil yang telah ditetapkan (Nur, Harun, \& Ibrahim, 2016). dalam hal ini keberadaan sekolah sangat berperan penting umtuk mengetahui semua kebutuhan fisik pendidikan, input dan output pendidikan. Tujuan pemenuhan semua kebutuhan tersebut dikembangkan dan didayagunakan dalam proses menyesuaikan pendidikan sesuai dengan perkembangan dan kebutuhan anak-anak bangsa disetiap pelosok negeri (Sulasmono \& Murjini, 2017), sehingga dapat memperkuat keberadaan sistem desentralisasi dalam pengembangan kurikulum pada siklus dan mekanisme administrasi sistem pendidikan nasional Indonesia yang diharapkan mampu membentuk peserta didik yang memiliki pengalaman dan wawasan yang luas, sebagai bekal dalam pengembangan potensi daerahnya. Mewujudkan budaya bangsa dan memperkuat kemandirian identitas nasional, meningkatkan mutu kehidupan dan lingkungannya, serta menumbuhkan kader 
penerus perjuangan bangsa dan pembangunan nasional (Subandijah, 1993).

Pendidikan wajib dan hak bagi setiap anak bangsa akan tetapi dewasa ini hak dan kewajiban dalam menempuh pendidikan cendrung diabatasi syarat, banyak anak-anak ingin tetap selalu diakui eeksistensinya dalam mencapai pendidikan dengan ukuran yang terlihat, sangat wajar dan sederhana hanya sekedar dapat mengisi hidupnya dengan wajar dimasa yang akan datang, dapat mengikuti pendidikan sampai tingkat tertinggi dan memungkinkan untuk menyalurkan bakat dan keterampilan sesuai dengan talentanya tanpa terhambatnya hak-hak anak memperoleh pendidikan walaupun dihantui keadaan krusial seperti kemiskinan yang semangkin menguat, kontrol sosial semangkin longgar dan terus melemah, keluarga rawan sosial semangkin bertambah dan biaya pendidikan semangkin tidak terjangkau yang jika semuanya dianggap biasa dan santai jumlah ketelantaran remaja usia sekolah secara kuantitatif akan terus bertambah. adanya latar berlakang mengenai kesenjangan pendidikan tersebut menjadi ide dirancangnya penelitian ini yang bertujuan untuk mengkonstruksikan dan mendeskripsikan bagaimana peran dan strategi SMP Terbuka sebagai salah satu solusi/wadah menembus masyarakat sampai lini terbawah untuk bersekolah tetapi tidak mengesampingkan kualitas layanan atau mutu.

\section{METODE PENELITIAN}

Penelitian ini merupakan penelitian kualitatif dengan pendekatan fenomenologi, pengumpulan data menggunakan teknik wawancara, observasi, studi dokumen, wawancara dilakukan dengan beberapa informan yaitu anak-anak SMP Terbuka, anak- anak Sekolah Induk, kepala sekolah, Pamong, guru bina, Stakeholder. Observasi dilakukan dengan cara ikut serta hadir selama 1 bulan dengan mengamati aktifitas anak-anak SMP Terbuka.

Instrumen pengambilan data selain peneliti sebagai instrument kunci, juga menggunakan alat perekam serta kamera untuk mengambil foto-foto dalam wawancara dilakukan secara bebas, agar tidak terkesan formal dan kritis. Dengan demikian data diperoleh mengalir seperti yang diinginkan. Pertanyaan yang di ajukan berkisar tentang apa saja yang mempengaruhi mutu dan daya beda yang dapat meningkatkan hasil belajar Anak-anak SMP Terbuka. Jawaban yang diperoleh baik yang direkam maupun yang dicatat kemudian disederhanakan sesuai fokus penelitian dan kemudian di analisis dengan rujukan teori-teori yang mendukung. Observasi dilakukan dengan pengamatan di setiap kegiatan yang baik terstuktur atau tidak terstruktur anak-anak SMP Terbuka dan kepala sekolah dengan maksud menjalin keakraban sehingga mereka dapat diajak berkomunikasi apa adanya tanpa ada rasa curiga. Laporan penelitian ini disusun dalam bentuk naratif untuk menjelaskan informasi yang diperoleh secara kualitatif.

\section{HASIL PENELITIAN DAN PEMBAHSAN}

Satu bentuk inovasi dalam pendidikan untuk menembus masyarakat yang termarjinalkan adalah dibentuknya pendidikan terbuka, yang dapat dikategorikan sebagai pendidikan semi formal. Sistem itu dikenal untuk dapat mengatasi masalah belajar khususnya bagi mereka yang karena berbagai macam kendala tidak memperoleh kesempatan untuk belajar yang lazim, seperti yang sudah dijelaskan diatas. sementara mereka mempunyai potensi untuk belajar, dan masih ada sumber belajar lain dapat dimanfaatkan untuk media belajar bagi anak-anak yang bersekolah di sekolah terbuka. Sistem pendidikan terbuka meliputi berbagai macam bentuk dengan berbagai macam sebutan seperti Pendidikan Jarak Jauh, Pendidikan Mandiri, Pendidikan Bermedia, Pendidikan Terkemas, Pendidikan Arah-diri (self directed education), Pendidikan Bebas, Pendidikan Laju-diri (self paced education), Pendidikan Korespondensi, dan berbagai istilah lain lagi. 
SMP Terbuka tidak dimaksudkan sebagai suatu sistem pendidikan jarak jauh yang terpisah dari SMP Induk. SMP terbuka merupakan "anak" yang berinduk pada SMP regular yang terdekat. sehingga belajar mengajar menjadi efektif karena para pendidik pun ada di dekat para siswa setiap saat diperlukan dan dimungkinkan. (Farozin, 2012) karakter SMP terbuka tersebut diharapkan menjawab probelema pada anak SMP terbuka yang ditemukan berdasarkan hasil observasi dan pemantauan terstruktur dari peneliti yang mana salah satu kesulitan mereka untuk bersekolah dikarenakan adanya kesamaan latar belakang dalam kehidupan mereka sehari-hari. tuntutan kewajiban menafkahi diri sendiri, mirisnya ditemukan juga sebagai tulang punggung dalam keluarga, berasal dari keluarga broken home dan banyak lainnya.

Cita-cita mulia pemerintah membagun SMP Terbuka patut di apresiasi, tetapi dengan berjalannya waktu muncul berbagai masalah yang ditemukan dilapangan seperti harapan terlihat tidak sesuai kenyataan secara gamblang pembuktiannya dibakukan karena masih banyaknya ditemukan anak-anak Indonesia belum juga bersekolah di SMP Terbuka atau yang sudah bersekolah di SMP Terbuka namun minat belajarnya tidak seperti yang diharapkan dengan kata lain, banyak keluarga belum mempercayakan sepenuhnya edukasi anak-anak mereka dengan berbagai alasan yang secara langsung berdampak terhadap dipahami minat sangat mempengaruhi proses, minat menempuh pendidikan pribadi anak-anak usia sekolah, serta suatu keadaan dimana seseorang mempunyai perhatian terhadap sesuatu dan disertai dengan keinginan untuk mengatahui dan mempelajari maupun membutuhkan lebih lanjut (Ramayulis, 2001).

Adapun terdampak karena kurangnya minat adalah anak bangsa itu sendiri serta lembaga belajar yang kekurangan anggota belajar, karena minat sangat besar pengaruhnya terhadap proses belajar, siswa yang berminat akan 68 mempelajari dengan sungguh sungguh karena ada daya tarik baginya (Bahri,1994). Salah satu yang menjadi penyebab dapat dilihat dan diteliti yang mengakibatkan kurangnya minat pergi sekolah untuk belajar bagi anak-anak SMP Terbuka adalah tidak terpenuhnya kebutuhan Psikologi serta bonus demografi yang dimaknai sebabagai kesempatan untuk menikmanti kesejateraan masyarakat dikarenakan potensi sumber daya manusia yang produktif menghasilkan barang/jasa kesehatan untuk keperluan masyarakat (Subijanto ,\&..2017).

Berdasarkan problema tersebut agar dapat menigkatkan partisipasi anak-anak, biasanya SMP Terbuka berupaya menginovasi dengan ajakan-ajakan yang menjanjikan serta didukung juga dengan kondisi anak, adanya daya beda yang mendukung mutu diharapkan dapat membawa minat belajar siswa SMP Terbuka, Komariah (2009) berkata "Sistem pendidikan nasional sudah mengatur segala proses pendidikan yang mencakup segala aspek. Salah satu faktor tersebut bermuara pada peningkatan mutu siapa saja yang terlibat pada penyelenggaraan SMP Terbuka dan pemerintah secara umum diperkuat dan diperjelas dalam PP no. 19/2005 tentang standar nasional pendidikan yang menjelaskan dalam pasal 91 bahwa:1. Setiap satuan pendidikan pada jalur formal dan nonformal wajib melakukan penjamin mutu pendidikan.2. Penjamin mutu pendidikan sebagiamana dimaksud pada ayat (1) bertujuan untuk memenuhi atau melampaui standar nasional pendidikan.3. Penjamin mutu pendidikan sebagaimana dimaksud pada ayat (1) dilakukan secara bertahap, sistematis, dan terencana dalam suatu program penjamin mutu yang memiliki target dan kerangka waktu yang jelas. Istilah belajar mandiri menggambarkan keadaan dimana anak SMP Terbuka tidak ditutut dengan berbagai peraturan halnya seperti anak-anak SMP induk atau Reguler lainnya. Namun tujuan mulia strategi belajar mandiri mungkin saja tidak berjalan seirama dengan psikologi kejiwaan anak. 
Pada umumnya anak tidak ingin dibedabedakaan apapun alasannya. Karena daya tangkap setiap anak berbeda. Apalagi peraturan sekolah mandiri yang mengikat suatu komunitas anak-anak putus sekolah terlihat berbeda dan terkesan diskriminatif.

Stigma atau kesan di masyarakat muncul tanpa dibentuk sama sekali, pendapat adanya anak kandung dan anak tiri pemerintah, anak kadung yaitu anak anak sekolah induk yang mendapat berbagai fasillitas sarana dan prasarana dan anak tiri pemerintah adalah anakanak SMP terbuka yang menerapkan sistem belajar mandiri dengan kata lain keterbatasan sarana dan prasarana. Sebagai contoh adalah gedung sekolah. Gedung atau fasilitas sekolah adalah ukuran atau simbol keterpunyaan yang sangat berpengaruh terhadap semangat dan minat serta keterlibatan dalam aktifitas sosial. Untuk diketahui gedung atau fasilitas ideal merupakan dambaan setiap anak didik adalah Bangunan atau fasilitas sekolah harus memenuhi kebutuhan jumlah ruang belajar. Jumlah ruang belajar dibuat berdasarkan perkiraan jumlah siswa yang akan masuk tahun yang akan datang datang, selain itu diperhatikan pula perkiraan jumlah siswa yang akan keluar baik karena putus sekolah, pindah sekolah, ataupun karena sudah lulus. bagi sekolah syarat pedagogis dalam suatu bangunan yang merupakan syarat yang sangat penting. Hal ini tidak boleh diabaikan mengingat bangunan sekolah merupakan tempat yang digunakan untuk proses pendidikan. syarat pedagogis dari gedung sekolah adalah; 1, ukuran ruangan yang proporsional,2. masuknya pencahayaan ,3. Sarana prasarana sesuai kebutuhan,4. Penggunaan warna yang sesuai 5. Aman, , 6. Menurut syarat kesehatan,7.situasi yang kondusif, 8. Dapat memungkinkan untuk memperluas tanpa memakan biaya lagi yang besar,9. Fleksibel,10. Memenuhi syarat keindahan, 11. Syarat ekonomis (Barnawi \& Arifin 2012)
Dari sisi sarana prasarana tidak perlu menjadi persoalan karena pada umumnya analisa permasalahan anak-anak SMP Terbuka adalah hak kepala sekolah SMP terbuka itu sendiri. Dalam regulasi yang menjadi kepala sekolah SMP Terbuka Merupakan kepala sekolah induk yang juga merangkap jabatan sebagai kepala sekolah SMP Terbuka. Dengan alasan tersebut maka kepala sekolah SMP Terbuka yang juga kepala sekolah SMP induk mengadopsi hampir 80 persen rencana strategi SMP Tebuka.

Pada saat pemantauan san pengumpulan informasi, peneliti menemukan sebuah fenomena yang tidak lazim, anak-anak SMP terbuka terkesan tidak mengikuti aturan baik cara berbusana maupun cara bersikap, sehingga penunjukan seorang pemimpin untuk SMP Terbuka dipertimbangkan adalah orang yang memahami keadaan yang mendasar tersebut. sehingga esensi pemimpin mengandung arti sebagai pelopor, berjalan dimuka, menuntun, membimbing, mendorong, mengambil langkah/prakarsa pertama, bergerak lebih awal, berbuat lebih dahulu memberi contoh, menggerakkan orang lain melalui pengaruh dan sebagainya berjalan dengan maksimal (Permadi, 1996:9). Kembali lagi pada saat melakukan pengamatan secara mendalam tersrbut tidak terlihat adanya pembedaan sikap yang diberikan kepala sekolah kepada dua sekolah yang dipimpinnya bahkan peneliti melihat kepala sekolah bekerja sepenuh hati demi meningkatkan kualitas seluruh komponen yang ada pada SMP Terbuka

Strategi tidak lepas dari peran pemimpin dalam temuan dilapangan kepala sekolah memegang kendali pengelolaan sekolah terbuka, dari rencana strateginya memunculkan peran tersendiri yang notabene menjadikan sekolah terbuka menjadi hunian anak bangsa kaum marjinal karena berpola dan tendensi akan naturalisasi kebiasaan peserta didik. Semua itu berkaitan dengan jiwa kepemimpinan dari seorang kepala sekolah yang erat kaitannya dengan pen- 
gertian mempelopori berjalan di muka, menuntun, membimbing, mendorong, mengambil langkah, prakarsa pertama, bergerak lebih awal, berbuat lebih dahulu, memberi contoh, menggerakkan orang lain melalui pengaruh (Fajri. EM \& Aprilia, 1980). Ternyata pemimpin mempunyai strategi dan langkah-langkah dalam upaya mempengaruhi banyak orang melalui komunikasi untuk mencapai tujuan (Dubrin, 2009 ) yang jika tidak dilakukan dengan tuntunan profesional akan sulit menghasilkan keputusan yang humanis (Saputra,.2019). Semangkin untuk dipahami bahwa Kepemimpinan adalah suatu kegiatan dalam membimbing suatu kelompok sedemikian rupa sehingga tercapai tujuan dari kelompok itu yaitu tujuan bersama. kepemimpinan adalah sekumpulan dari serangkaian kemampuan dan sifat-sifat kepribadian, dan intisari dari ajakan nelaksanakan tugas-tugas yang dibebankan kepadanya dengan rela penuh semangat dan kegembiraan batin, serta merasa tidak terpaksa (Purwanto,1992). Jika untuk memimpin merupakan sebuah kemampuan yang perlu dimiliki oleh seorang kepala sekolah dalam menggerakkan seluruh sumber layaknya organisasi terutama sumber daya manusianya untuk melakukan apa yang diharapkan. Kemampuan inilah yang akan menentukan bahwa seorang pemimpin tersebut baik atau tidak baik (Anwar, 2011).

Memimpin untuk mencari suatu strategi adalah kegiatan untuk .mempengaruhi orang, agar mau berusaha mencapai tujuan atau sasaran tertentu bahkan Sebagian ahli menganggap bahwa inti manajemen adalah kepemimpinan (Komaruddin, 1994). (Sagala, 2006) mengatakan kepemimpinan adalah suatu pokok dari keinginan manusia yang besar untuk menggerakkan potensi organisasi, kepemimpinan juga salah satu penjelas yang paling populer untuk keberhasilan. Seorang pemimpin yang dapat melakukan strateginya dalam meningkatkan minat anak-anak SMP Terbuka adalah pemimpin yang mengerti dan peduli karena pemimpin yang mau mengerti dan peduli dapat melakukan 70 berbagai strategi untuk meningkatkan minat anak-anak SMP Terbuka agar tercapainya tujuan pendidikan. Adapun sumber kekuasaan menurut French \& Raven, dikutip (Sarwono,2005), ada lima kategori kekuasaan, kategori: yaitu: Pertama, Kekuasaan Paksaan (Coeráve Power), Kedua, kekuasaan Imbalan (insentif Power), ketiga, Kekuasaan Sah (Legitímate Power), Keempat, Kekuasaan Pakar (Expert Power), Kelima, Kekuasaan Rujukan (Rejerent Power. Sedangkan menurut Rifai (2003:32-33) menyatakan pemimpin yang efektif adalah 1. luwes, 2. Sadar mengenai diri,kelompok, dan situasi.3, penuh komunikasi dengan bawahan 4, Piawai .5, bertanggung jawab dan fokus .6, memastikan bahwa keputusan yang dibuat sesuai dan tepat waktu baik secara individu maupun kelompok. 7, berinovasi.8, menepati janji yang diberikan kepada bawahan.9.senang melakukan evaluasi yang memunculkan strategi yang membawah solusi dengan berbagai tuntunan teori yang berdasarkan prinsif kesempurnaan dan ketepatan sehingga dapat dilakukan sebagai strategi mutu pada SMP Terbuka yang berpegangan terhadap peraturan sebagai landasan kepala sekolah dalam mengambil keputusan strategi untuk menciptakan output dan outcome yang berkualitas dan memiliki kuantitas peserta didik.

\section{SIMPULAN DAN SARAN Simpulan}

SMP Terbuka adalah sekolah yang menjadi alternatif masyarakat marjinal memperoleh pendidikan yang dibiayai pemerintah. Dalam perencanaan Rencana Strategis SMP Terbuka masih bergantung sepenuhnya pada SMP Induknya, namun sebagai sekolah yang juga mempunyai visi dan misi, SMP Terbuka sudah sepantasnya mengoftimalkan strateginya, strategi SMP terbuka dalam penelitian ini yaitu strategi naturalisasi dimana strategi ini bercirikan pada konsep penyesuaian keadaan yang dianggap berhasil menyentuh kalangan masyara- 
kat bawah dengan merancang suatu pola pendidikan yang mempertimbangkan keadaan peserta didik, dengan harapan dapat menjadi referansi sekolah murah dengan fasilitas pembekalan keterampilan sehingga bermuara pada terbentuknya suatu mutu. Layaknya sekolah negeri umum, dalam proses memberi layanan pendidikan, SMP Terbuka berpeluang tetap konsisten dalam eksistensinya dimasa yang akan datang, ternyata SMP Terbuka memiliki gambaran yang kuat dalam mencerdaskan kehidupan bangsa dikarenakan keunikan yang dimiliki SMP Terbuka dari daya bedanya tersebut, program menembus anak-anak usia sekolah yang tidak tersentuh, dan memberikan mereka keterampilan sebagai daya beda dari SMP terbuka menjadi bekal bagi anak didik memperoleh dan memastikan kehidupan yang layak setelah tamat maupun semasa menimba ilmu.

\section{Saran}

Berdasarkan kesimpulan diatas maka di sarankanlah beberapa saran yang baik untuk kemajuan pendidikan Indonesia, yang pertama untuk keluarga besar penyelenggara SMP terbuka tetap dan pertahankan daya beda demi menjangkau anak-anak bangsa yang tidak semua mampu mengikuti pendidikan formal seperti anak-anak usia sekolah pada umumnya. kedua kepada pemerintah pelayanannya diharapkan lebih lagi menembus masyarakat yang termarjinalkan dengan cara memperbesar anggaran pada setiap lini SMP terbuka. Ketiga kepada masyarakat agar selalu berfikir bahwa akan menjadi suatu keuntungan kepada anakanak jika bersekolah di SMP Terbuka karena daya bedanya.

\section{DAFTAR PUSTAKA}

Anwar, U. K. (2011). Kepemimpinan Pesantren, Jambi: Sulthan Thaha Press

Bahri, S. (1994). Prestasi Belajar dan Kompetensi Guru, Surabaya : PT Usaha Nasional.
Barus, G. (2015). Menakar Hasil Pendidikan Karakter Terintegrasi di SMP. Jurnal Cakrawala Pendidikan, 2(2), 222-233. https://doi.org/10.21831/cp.v2i2.4827

Barnawi \& Arifin, M. (2012). Manajemen Saran dan Prasarana Sekolah, Jogjakarta: Ar-Ruzz Media

Dubrin, A. J. (2009). The Complete Ideal'S Guides To Leadership, Terjemahan Tri Wibowo BS, Jakarta: Prenada

Efendi, M. (1996). Manajemen Suatu Pendekatan Berdasarkan Ajaran Islam

Fahri E., Zul dan Aprilia, S.R. (2008). Kamus Lengkap Bahasa Indonesia, Bandung: Hasta

Farozin, M. (2012). Pengembangan Model Bimbingan Klasikal Untuk Meningkatan Motivasi Belajar Siswa SMP. Jurnal Cakrawala Pendidikan, (1), 143-156.

https://doi.org/10.21831/cp.v0i1.1472

Hendrowobowo, L. (1994). Kajian ilmiah tentang ilmu pengetahuan. Cakrawala Pendidikan, $\operatorname{XIII}(2), 123-133$.

Kastawi. N.S \& Yuliejantiningsih, Y. (2019). Pengembangan keprofesian berkelanjutan guru untuk meningkatkan mutu pendidikan. Jurnal Kelola M.P UKSW, VI(2), 157-159

Komariah, A (2009). Manajemen Pendidikan. Bandung: Alfabeta

Komaruddin.0(1994). Ensiklopedia Manajemen, Jakarta: Ikrar Mandiri Abadi

Pardjono (2016). Peran Industri dan Lembaga Pendidikan non Formal dalam Menyiapkan Tenaga Kerja. Cakrawala Penkan,03(3).0https://doi.org/10.20831 /cp.v3i3.8675 
Nur, M., Harun, C. Z., \& Ibrahim, S. (2016). Pendidikan Pada SDN Dayah Guci Kabupaten Pidie. Administrasi Pendidikan, 4(1), 93-103.

Pendidikan, I., \& Tantangan, D. (1996). Ilmu Pendidikan dalamTantangan. Cakrawala Pendidikan,1(1).0https://doi.org/10.21831/cp.v $1 \mathrm{i} 1.9198$

Permadi, K.,(1996). Pemimpin dan kepemimpinan dalam manajemen, Jakarta : Rieneka Cipta

Purwanto, N. (1992) . Administrasi Supervisi Pendidikan, Bandung: Alumni

Ramayulis. (2001). Metodologi Pengajaran Agama Islam, Jakarta: Kalam Mulia.

Rivai, V. (2003). Kepemimpinan dan Perilaku Organisasi, Jakarta: Rajagrafindo Persada

Sagala, S. (2006). Administrasi Pendidikan Kotemporer. Bandung: Alfabeta

Saputra, B. R. (2019). Strategi Pendekatan Peran Sebagai Pemimpin Dan Keluarga Yang Diterapkan Kepala Sekolah Untuk Meningkatkan Komitmen Kerja Guru Di Sekolah. Jurnal Kelola M.P UKSW,VI(2), 122159
Sarwono, S.W. (2005). Psikologi Sosial, Jakarta : Balai Pustaka

Subandijah. (1993). Suatu Mekanisme Ad-ministrasi Kurikulum Masa Kini. Jurnal Cakrawala Pendidikan, 13-23.

Subijanto, S., Suprastowo, P., Jakaria, Y., Hendarman, H., Waluyo, P., \& Winigsih, L. H. (2017). Program Pendidikan Menengah Universal Sebagai Persiapan Wajib Belajar Duabelas Tahun. Jurnal Cakrawala Pendidikan, 36(1), 1-12. https://doi.org/10.21831/cp.v35i1.1211 9

Sulasmono, B. S., dan Murjini. (2017). Evaluation on the Performance of School Committee in. Cakrawala Pendidikan, Th. XXXVI(1), 113-121.

Suriansyah, A., \& . A. (2015). Strategi Kepemimpinan Kepala Sekolah, Guru, Orang Tua, dan Masyarakat Dalam Membentuk Karakter Siswa. Jurnal Cakrawala Pendidikan, 2(2), 234-247. https://doi.org/10.21831/cp.v2i2.4828

Wahab, A. A. (2008). Anatomi Organisasi dan Kepemimpinan Pendidikan, Bandung: UPI dan Alfabeta 